Research Paper

\title{
Efficacy and Safety of Ipilimumab plus Chemotherapy for Advanced Lung Cancer: A Systematic Review and Meta-Analysis
}

\author{
Hongman Zhang*, Jie Shen*, Lilan Yi, Wei Zhang, Peng Luo ${ }^{\bowtie}$, Jian Zhang ${ }^{\bowtie}$ \\ Department of Oncology, Zhujiang Hospital, Southern Medical University, 253 Industrial Avenue, Guangzhou, 510282, Guangdong, People's Republic of China. \\ *These authors (Hongman Zhang and Jie Shen) contributed equally to this study and should be considered as co-first authors. \\ $\triangle$ Corresponding authors: Dr. Peng Luo, Dr. Jian Zhang, Department of Oncology, Zhujiang Hospital, Southern Medical University, 253 Industrial Avenue, \\ Guangzhou, 510282, Guangdong, People's Republic of China. Affiliation: Department of Oncology, Zhujiang Hospital, Southern Medical University. E-mail \\ address: luopeng@smu.edu.cn (Peng Luo) blacktiger@139.com (Jian Zhang). Fax number: +86 020-61643888 \\ (C) Ivyspring International Publisher. This is an open access article distributed under the terms of the Creative Commons Attribution (CC BY-NC) license \\ (https://creativecommons.org/licenses/by-nc/4.0/). See http://ivyspring.com/terms for full terms and conditions.
}

Received: 2018.05.20; Accepted: 2018.08.21; Published: 2018.11.11

\begin{abstract}
Lung cancer is the leading cause of cancer-related deaths worldwide, with poor prognosis in advanced lung cancer patients. Platinum-based chemotherapy has always been a first-line treatment for the majority of advanced lung cancer patients, but its long-term survival benefit is limited. Ipilimumab is an immune drug that targets the CTLA-4 protein in T cells. Therefore, we evaluated the efficacy and safety of adding ipilimumab to simple chemotherapy for patients with advanced lung cancer. We searched literatures in PubMed, Web of Science, EMBASE, the Cochrane Library and cliniclatrials.gov. The primary end points of this assessment were overall survival (OS), progression-free survival (PFS) and immune-related PFS(irPFS) of lung cancer patients. Other end points were objective response rate (ORR), disease control rate (DCR) and safety. The results of this study will be presented by the risk ratio (RR) of the endpoints and the $95 \%$ confidence interval (Cl) of the various effect sizes. And when the $p$ value is less than 0.05 , we think there is a statistical difference. Finally, 6 RCTs and 2,037 patients including 953 with advanced or recurrent non-small cell lung cancer (NSCLC) and 1084 with extensive-disease small-cell lung cancer (ED-SCLC) were identified. Among them, 1089 received immunochemotherapy, and 948 patients received chemotherapy alone. Immunochemotherapy can't improve OS (6months: risk ratio $(R R)=0.97$ $P=0.11$; lyear: $R R=1.05 P=0.36), O R R(R R=1.00 P=0.95)$ and $D C R(R R=0.92,95 \% C l \quad 0.85-1.00$, $\mathrm{P}=0.04$ ) of patients with lung cancer compared to pure chemotherapy, but it can improve the PFS (6months: $R R=1.16 P=0.02$; lyear: $R R=1.39 P=0.02$ ) and 6months-irPFS( $R R=1.60 \quad P=0.004)$. However, due to the addition of ipilimumab, the immune-related toxicities are more apparent in immunochemotherapy group.
\end{abstract}

Key words: advanced lung cancer, ipilimumab, chemotherapy, meta-analysis, systematic review

\section{Introduction}

Lung cancer is the leading cause of cancerrelated deaths worldwide[1], with an estimated 18 million new cases and 16 million deaths worldwide each year[2]. Lung cancer is divided into two primary types: small cell lung cancer (SCLC) and non-small cell lung cancer (NSCLC). SCLC accounts for approximately $15 \%$ of all lung cancers, while NSCLC accounts for approximately $85 \%$ of all lung cancers[3].
Most lung cancer patients are in the middle and late stages of diagnosis, with a 5-year survival rate of $<15 \%$, moreover, the 2-year survival rate of patients with SCLC is as low as $9 \%$, whereas the mortality rate during the last five years after diagnosis in patients with SCLC is as high as $90 \%$. Therefore, the prognosis of patients with advanced lung cancer is very poor[4, 5]. The main treatment methods for lung cancer 
include surgery, chemotherapy, radiotherapy and immunotherapy. Platinum-based chemotherapy is most commonly used in patients with advanced or recurrent NSCLC and ED-SCLC (Extensive Disease Small Cell Lung Cancer)[3, 6, 7]. However, the long-term benefit of first-line chemotherapy is limited, and some studies showed that median overall survival was only 8 months in patients with advanced NSCLC patients, and only 9 months in the patients with ED-SCLC $[8,9]$. In recent years, biological agents, such as bevacizumab and cetuximab, among others, have been added to chemotherapy regimens. These regimens have been compared with chemotherapy alone, and these combinations have not revealed an obvious difference in survival, and thus we urgently need novel effective treatments[10-13].

Cytotoxic $\mathrm{T}$ lymphocyte-associated antigen-4 (CTLA-4) is a type of leukocyte differentiation antigen, is a transmembrane receptor on $\mathrm{T}$ cells and shares B7 molecular ligands with CD28. The binding of CD28 following antigen receptor engagement provides a costimulatory signal required for $\mathrm{T}$ cell activation. However, upon binding B7 molecules, CTLA-4 induces $\mathrm{T}$ cell reactivity, and it participates in the negative regulation of the immune response, which is a negative regulator of $\mathrm{T}$ lymphocytes [14, 15]. Ipilimumab is a completely anthropogenic IgG1 type of monoclonal antibody that can specifically hinder the binding of CTLA-4 to its ligand (CD80 / CD86) and that can enhance the $T$ cell response in vivo and in vitro. Ipilimumab can then stimulate tumorspecific $\mathrm{T}$ cell proliferation, which leads to the infiltration of $\mathrm{T}$ cells into the tumor, and ultimately, tumor regression[16-19]. Early clinical trials of ipilimumab demonstrated its anti-tumor activity against multiple solid tumors[20, 21]. In a preclinical study model, cisplatin can increase the expression of FAS-cell death receptors on tumor cells, thereby enhancing CTL -mediated anti-tumor immunity[22]. In a preclinical tumor model, certain chemotherapy regimens can increase the anti-tumor activity of anti-CTLA-4 antibodies. In a pre-clinical mouse tumor model, ipilimumab blockade of CTLA-4 has been shown to enhance the efficacy of chemotherapy[23, 24]. This demonstrates that the combination of ipilimumab and chemotherapy is synergistic.

To further clarify the efficacy and safety of chemotherapy combined with ipilimumab immunotherapy for lung cancer patients, we conducted a meta-analysis on previous clinical studies, and more specifically, on relevant Randomized Controlled Trials (RCTs). We hope that this study will provide evidence-based medicine for clinical application.

\section{Materials and methods}

\section{Search strategy}

This meta-analysis is based on the PRISMA guidelines (Supplementary Table S1). We searched for studies in PubMed, Web of Science, EMBASE, the Cochrane Library and cliniclatrials.gov and did not have limits regarding the date; the final retrieval occurred on 2018/01/24. The searching keywords were Lung Neoplasms, Ipilimumab, and randomized controlled trial. The specific papers retrieved from each database are provided in the Supplementary material (Supplementary Table S2).

\section{Eligibility/Exclusion criteria}

\section{Inclusion criteria}

- Population studied: adults (> 18 years of age) with a diagnosis of lung cancer with the pathological type, including NSCLC and SCLC;

- Types of studies: randomized controlled trials;

- Intervention measures: the control group received chemotherapy alone, and the experimental group received the same chemotherapy regimen combined with ipilimumab immunotherapy;

- Endpoints: overall survival (OS), progressionfree survival (PFS), objective response rate (ORR), disease control rate (DCR), immune-related (ir)-PFS/ORR/DCR, and events that show efficacy and safety.

- Studies published in English.

\section{Exclusion criteria}

- It has been reported that literature that focuses on other unrelated tumor types or on early NSCLC and LD-SCLC (limited-disease small cell lung cancer) will not be included;

- Review articles, meta-analyses, case reports, editorials, single-arm trials, and studies on other types of non-RCTs will not be included.

\section{Study Selection and Data Extraction}

Two reviewers (Hm Zhang, J Shen) independently evaluated the title and abstract of each document according to the inclusion criteria and then conducted a full-text retrieval evaluation of the documents that conformed to the inclusion criteria. The selection of the research and the data extraction were independently performed by two investigators, who finally reached a consensus. Any disagreements were discussed and resolved by a third investigator ( $P$ Luo).

The primary end points of this assessment were the 6-month/1-year OS, the 6-month/1- year PFS and 
the 6-month/1-year irPFS of lung cancer patients. Other end points were the ORR, DCR, irORR, irDCR, and safety. Moreover, the meta-analysis also includes data on complete response/immune-related complete response (CR/irCR), partial response/immunerelated partial response (PR/irPR), progressive disease/immune-related progressive disease (PD/ irPD), stable disease/immune-related stable disease $(\mathrm{SD} /$ irSD). Furthermore, the data on toxic adverse events of the hematologic system, dermatological system, gastrointestinal system, neuromuscular system and other areas of the body was also summarized.

The following data were extracted: the first author's last name, country and territory, study type, published year, the study period, the number of subjects in the test group and control group and the percentage of females in each group, histological type, tumor stage, intervention and treatment time, and the efficacy and safety results.

\section{Quality Assessment}

Two investigators (HM Zhang, J Shen) used the Cochrane Collaboration's risk of bias tool to assess the quality of the methods used in the included RCTs. The assessment included the following: sequence generation, allocation concealment, blinding, incomplete outcome data addressed, free of selective outcome reporting, and other possible sources of bias[25]. Each project is classified as low risk, high risk, and unknown risk for the RCT evaluation. In the same way, the two investigators independently conducted the literature quality assessment and finally reached an agreement. Any disagreements were discussed and resolved by a third investigator (P Luo).

\section{Statistical analysis}

We used Review Manager 5.3 software (Cochrane Library, Oxford, UK) to perform a statistical analysis of the data, and the corresponding subgroup analyses for the end points of SCLC and NSCLC were also conducted[26]. The results of this study are presented by the risk ratio (RR) of the endpoints and the $95 \%$ confidence interval (CI) of the various effect size. All $p$ values are bilateral, and $p$ values less than 0.05 indicate a significant difference. In addition, the $\mathrm{I}^{2}$ statistic test was used to evaluate the heterogeneity of the data in the study group, and an $\mathrm{I}^{2}$ less than $50 \%$ indicated no obvious heterogeneity[27]. When no obvious heterogeneity was found among the studies, the fixed effect model was used, but otherwise, the random effect model was used. In addition, a sensitivity analysis was conducted to assess the stability of the results. We estimated the publication bias by evaluating the symmetry of the funnel plot; in addition, the potential publication bias was measured by Begg's and Egger's test using STATA software[28, 29].

Ethics committee approval is not applicable in this meta-analysis.

\section{Results}

\section{Study selection}

319 potential relevant studies were retrieved from 5 databases, and 248 remained after the duplicate literatures were removed. In all, 241 studies were excluded after the title and abstract were read; these excluded studies consisted of irrelevant studies, reviews, case studies, meta-analyses, and studies not published in English. Then, according to the inclusion criteria described above, the authors further evaluated the suitability of the other seven articles. Next, we excluded non-randomized controlled clinical studies and single-arm studies. Finally, four studies[30-33] were included in the final meta-analysis. When a study featured multiple experimental groups but only one control group, we divided the control group into two groups so that each corresponded with the two experimental groups, and for dichotomous outcomes, both the number of events and the total number of patients were divided[34]. The studies by Lynch (2012)[30] and Reck (2013)[31] were thus divided each control group into two groups. Finally, this meta-analysis included 6 clinical randomized controlled studies, and the PRISMA flowchart of the study is shown in Figure 1.

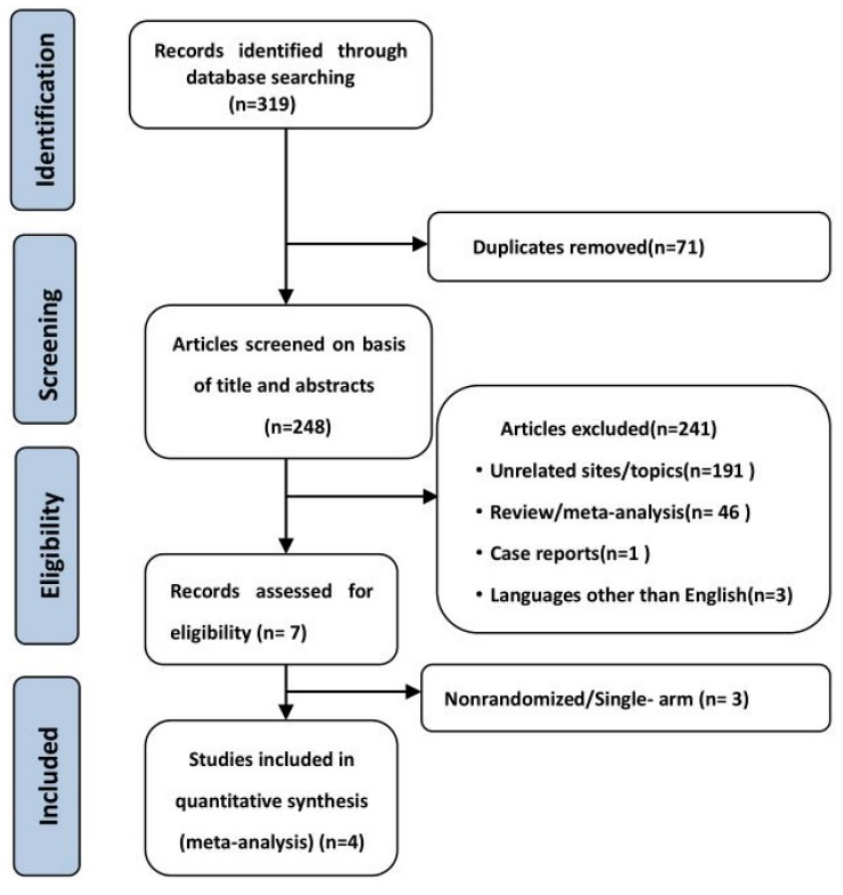

Figure 1. Flowchart of study selection. 
Table 1. Baseline characteristics

\begin{tabular}{|c|c|c|c|c|c|c|c|c|c|}
\hline \multirow[t]{2}{*}{ Authors } & \multirow{2}{*}{$\begin{array}{l}\text { Country } \\
\text { Or } \\
\text { Territory }\end{array}$} & \multirow[t]{2}{*}{$\begin{array}{l}\text { Study } \\
\text { period }\end{array}$} & \multirow[t]{2}{*}{$\begin{array}{l}\text { Publishe } \\
\text { d year }\end{array}$} & \multicolumn{2}{|c|}{$\begin{array}{l}\text { No. of patients } \\
\text { (Female \%) }\end{array}$} & \multirow[t]{2}{*}{$\begin{array}{l}\text { Histology } \\
\text { type }\end{array}$} & \multirow[t]{2}{*}{$\begin{array}{l}\text { Clinical } \\
\text { stages }\end{array}$} & Ipilimumab & \multirow[b]{2}{*}{ ency/No. of cycles } \\
\hline & & & & ipilimumab & placebo & & & Drugs/Dosage $\left(\mathrm{mg} / \mathrm{m}^{2}\right) /$ Frequer & \\
\hline $\begin{array}{l}\text { Lynch,T., } \\
\text { Et al.(a) } \\
{[30]}\end{array}$ & $\begin{array}{l}\text { US, } \\
\text { Europe } \\
\text { and India }\end{array}$ & $\begin{array}{l}2008- \\
2010\end{array}$ & 2012 & $70(24)$ & $33(13)$ & NSCLCa & $\mathrm{IIIB} c / \mathrm{IV}^{\mathrm{d}}$ & $\begin{array}{l}\text { If }(10 \mathrm{mg} / \mathrm{kg})+\operatorname{Pacg}\left(175 \mathrm{mg} / \mathrm{m}^{2}\right) \\
+\operatorname{Carb}^{\mathrm{h}}(\mathrm{AUC}=6) ; \mathrm{q} 3 \mathrm{w} ; \leq 18 \mathrm{w}+ \\
\text { followed by } \\
\text { If }(10 \mathrm{mg} / \mathrm{kg}) ; \mathrm{q} 12 \mathrm{w} ; \text { to PD }\end{array}$ & $\begin{array}{l}\text { Placebo+Pacg }\left(175 \mathrm{mg} / \mathrm{m}^{2}\right) \\
+ \text { Carbh }(\mathrm{AUC}=6) ; \mathrm{q} 3 \mathrm{w} ; \leq 18 \mathrm{w} \\
\text { followed by } \\
\text { Placebo;q12w; to PD }\end{array}$ \\
\hline $\begin{array}{l}\text { Lynch,T., } \\
\text { et al.(b) } \\
{[30]}\end{array}$ & $\begin{array}{l}\text { US, } \\
\text { Europe } \\
\text { and India }\end{array}$ & $\begin{array}{l}2008- \\
2010\end{array}$ & 2012 & $68(28)$ & $33(13)$ & NSCLCa & $\mathrm{IIIBc} / \mathrm{IVd}^{\mathrm{d}}$ & $\begin{array}{l}\text { If }(10 \mathrm{mg} / \mathrm{kg})+\operatorname{Pacg}\left(175 \mathrm{mg} / \mathrm{m}^{2}\right) \\
+\operatorname{Carb}^{\mathrm{h}}(\mathrm{AUC}=6) ; \mathrm{q} 3 \mathrm{w} ; \leq 18 \mathrm{w} \| \\
\text { followed by } \\
\text { If(10mg/kg);q12w; to PD }\end{array}$ & $\begin{array}{l}\text { Placebo+Pacg }\left(175 \mathrm{mg} / \mathrm{m}^{2}\right) \\
+ \text { Carbh }(\mathrm{AUC}=6) ; \mathrm{q} 3 \mathrm{w} ; \leq 18 \mathrm{w} \\
\text { followed by } \\
\text { Placebo;q12w; to PD }\end{array}$ \\
\hline $\begin{array}{l}\text { Reck, M., } \\
\text { et } \\
\text { al.(a)[31] }\end{array}$ & $\begin{array}{l}\text { US, } \\
\text { Europe } \\
\text { and India }\end{array}$ & $\begin{array}{l}2008- \\
2011\end{array}$ & 2013 & $43\left(\mathrm{NR}^{*}\right)$ & $23\left(\mathrm{NR}^{*}\right)$ & SCLCb & ED-SCLCe & $\begin{array}{l}\text { If }(10 \mathrm{mg} / \mathrm{kg})+\operatorname{Pacg}\left(175 \mathrm{mg} / \mathrm{m}^{2}\right) \\
+\operatorname{Carb}^{\mathrm{h}}(\mathrm{AUC}=6) ; \mathrm{q} 3 \mathrm{w} ; \leq 18 \mathrm{w} \| \\
\text { followed by } \\
\text { If(10mg/kg);q12w; to PD }\end{array}$ & 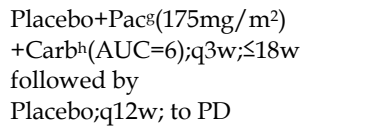 \\
\hline $\begin{array}{l}\text { Reck, M., } \\
\text { et al.(b) } \\
{[31]}\end{array}$ & $\begin{array}{l}\text { US, } \\
\text { Europe } \\
\text { and India }\end{array}$ & $\begin{array}{l}2008- \\
2011\end{array}$ & 2013 & $42\left(\mathrm{NR}^{*}\right)$ & $22\left(\mathrm{NR}^{*}\right)$ & SCLC ${ }^{b}$ & ED-SCLCe & $\begin{array}{l}\text { If }(10 \mathrm{mg} / \mathrm{kg})+\operatorname{Pacg}\left(175 \mathrm{mg} / \mathrm{m}^{2}\right) \\
+\operatorname{Carb}^{\mathrm{h}}(\mathrm{AUC}=6) ; \mathrm{q} 3 \mathrm{w} ; \leq 18 \mathrm{w}+ \\
\text { followed by } \\
\text { If }(10 \mathrm{mg} / \mathrm{kg}) ; \mathrm{q} 12 \mathrm{w} ; \text { to PD }\end{array}$ & $\begin{array}{l}\text { Placebo+Pacg }\left(175 \mathrm{mg} / \mathrm{m}^{2}\right) \\
+ \text { Carbh }(\mathrm{AUC}=6) ; \mathrm{q} 3 \mathrm{w} ; \leq 18 \mathrm{w} \\
\text { followed by } \\
\text { Placebo;q12w; to PD }\end{array}$ \\
\hline $\begin{array}{l}\text { Reck, M., } \\
\text { et al. [32] }\end{array}$ & $\begin{array}{l}\text { North } \\
\text { America, } \\
\text { South } \\
\text { America, } \\
\text { Europe } \\
\text { and Asia }\end{array}$ & $\begin{array}{l}2011- \\
2015\end{array}$ & 2016 & $478(34)$ & $476(32)$ & SCLCb & ED-SCLCe & $\begin{array}{l}\text { If }(10 \mathrm{mg} / \mathrm{kg}), \text { cycle3-6+Etoi }(100 \\
\left.\mathrm{mg} / \mathrm{m}^{2}\right)+ \text { Cispi } \\
\left(75 \mathrm{mg} / \mathrm{m}^{2}\right) / \operatorname{Carb}^{\mathrm{h}}(\mathrm{AUC}=5) \\
\text { cycle1-4;q3w } \\
\text { followed by } \\
\text { If }(10 \mathrm{mg} / \mathrm{kg}) ; \mathrm{q} 12 \mathrm{w} ; \text { to PD }\end{array}$ & $\begin{array}{l}\text { Placebo,cycle3-6+Etoi }\left(100 \mathrm{mg} / \mathrm{m}^{2}\right. \\
)+ \text { Cispi }\left(75 \mathrm{mg} / \mathrm{m}^{2}\right) / \mathrm{Carb}^{\mathrm{h}}(\mathrm{AUC}= \\
\text { 5),cycle1-4;q3w; } \\
\text { followed by } \\
\text { Placebo;q12w; to PD }\end{array}$ \\
\hline $\begin{array}{l}\text { Govindan } \\
\text {,R.,et } \\
\text { al.[33] }\end{array}$ & $\begin{array}{l}\text { North } \\
\text { America, } \\
\text { South } \\
\text { America, } \\
\text { Europe } \\
\text { and Asia }\end{array}$ & $\begin{array}{l}2011- \\
2015\end{array}$ & 2017 & $388(16)$ & $361(14)$ & NSCLCa & $\begin{array}{l}\mathrm{IV}^{\mathrm{d}} \text { or } \\
\text { recurrent }\end{array}$ & $\begin{array}{l}\text { If }(10 \mathrm{mg} / \mathrm{kg}), \text { cycle3-6+Pacg }(175 \\
\left.\mathrm{mg} / \mathrm{m}^{2}\right)+ \text { Carb } \\
(\text { AUC }=6), \text { cycle } 1-6 ; \mathrm{q} 3 \mathrm{w} \\
\text { followed by } \\
\text { If }(10 \mathrm{mg} / \mathrm{kg}) ; \mathrm{q} 12 \mathrm{w} ; \text { to PD }\end{array}$ & $\begin{array}{l}\text { Placebo,cycle3-6+Pacg }(175 \mathrm{mg} / \mathrm{m} \\
\text { 2)+Carbh(AUC=6), cycle1-6;q3w; } \\
\text { followed by } \\
\text { If }(10 \mathrm{mg} / \mathrm{kg}) ; \mathrm{q} 12 \mathrm{w} \text {; to PD }\end{array}$ \\
\hline
\end{tabular}

a: Non-Small-Cell Lung Cancer; b: Small Cell Lung Cancer; c: Clinical stages IIIB is $\mathrm{T}_{1-4} \mathrm{~N}_{3} \mathrm{M}_{0}, \mathrm{~T}_{4} \mathrm{~N}_{2-3} \mathrm{M}_{0}$; $\mathrm{d}$ : Clinical stages IV is $\mathrm{T}_{1-4} \mathrm{~N}_{0-3} \mathrm{M}_{1}$; $\mathrm{e}$ : extensive stage-Small Cell Lung Cancer is the lesion exceeds the restricted range; f: Ipilimumab; g: Paclitaxel; $\mathrm{h}$ : Carboplatin; i: Etoposide; i: Cisplatin. TNM stages: The Tumor, Node, Metastasis (TNM) staging system, adopted by both the Union for International Cancer Control (UICC) and the American Joint Committee on Cancer (AJCC), and the new edition (8th) of the staging manual was published in January 2017[35]. +: concurrent-ipilimumab regimen (four doses of ipilimumab/paclitaxel (Taxol)/carboplatin followed by two doses of placebo/paclitaxel/carboplatin). \|: phased-ipilimumab regimen (two doses of placebo/paclitaxel/carboplatin followed by four doses of ipilimumab/paclitaxel/carboplatin). ':NR: not reported.

\section{Study Characteristics and quality appraisal}

The six studies included 2,037 patients with lung cancer, including 953 patients with advanced or recurrent NSCLC and 1084 cases of ED-SCLC. Among them, 1089 received immunochemotherapy, and 948 patients received chemotherapy alone. The baselines values were comparable because all studies focused primarily on platinum-based chemotherapy. The characteristics of each study are in Table 1[35]. The bias risk assessment of each study is summarized in Supplementary Figure S1.

\section{Effect measures of ipilimumab vs. placebo for various lung cancers}

This meta-analysis did not demonstrate that immunochemotherapy increased the 6-month OS compared with chemotherapy alone (79.6\% VS. 83.2\%, $\mathrm{RR}=0.97,95 \% \mathrm{CI}$ 0.93-1.01, $\mathrm{P}=0.11)$, and this result did not indicate much heterogeneity $(\mathrm{I}=21 \%, \mathrm{P}=0.28)$. Even more, subgroup analysis suggested that the OS of NSCLC patients in the immunochemotherapy group was inferior to the chemotherapy alone group, and had statistical significance $(77.0 \%$ VS. $84.8 \%$, $\mathrm{RR}=0.92,95 \% \mathrm{CI}$ 0.87-0.98, $\mathrm{P}=0.009$ ). The 6-month PFS of the immunochemotherapy group was significantly better than that of the chemotherapy alone group, and no heterogeneity was found among the studies $(35.0 \%$ VS. $30.1 \%$, RR $=1.16,95 \% \mathrm{CI} 1.02-1.31, \mathrm{P}=0.02),\left(\mathrm{I}^{2}=0 \%\right.$, $\mathrm{P}=0.71$. The analysis showed that immunochemotherapy leads to a significant improvement in the 6-month-irPFS compared with chemotherapy alone (47.5\% VS. 29.7\%, RR=1.60, 95\%CI 1.16-2.20, $\mathrm{P}=0.004$ ), with no heterogeneity among the studies $\left(\mathrm{I}^{2}=0 \%\right.$, $\mathrm{P}=0.86$ ). Additionally, the subgroup analysis indicated that NSCLC and SCLC both showed significant differences between groups (NSCLC: $46.4 \%$ VS. $30.3 \%, \mathrm{RR}=1.53,95 \% \mathrm{CI} 1.02-2.30, \mathrm{P}=0.04$; SCLC: $49.4 \%$ VS. $28.9 \%$, RR $=1.71,95 \%$ CI $1.03-2.84$, $\mathrm{P}=0.04$ ). The 1-year OS rates of the intervention group and the control group were $46.2 \%$ and $44.3 \%$, respectively. Compared with the control groups, immunochemotherapy did not show survival benefits in the combined 1-year OS analysis ( $R R=1.05,95 \% C I$ 0.95-1.15, $\mathrm{P}=0.36$ ), and the results indicated little heterogeneity $\left(\mathrm{I}^{2}=0 \%, \mathrm{P}=0.58\right)$. The 1 -year PFS of the immunochemotherapy group and the chemotherapy only group was $10.8 \%$ and $7.9 \%$, respectively. The 1-year PFS of the immunochemotherapy group was significantly better than that of the chemotherapy group, with no heterogeneity found among the studies ( $R R=1.39,95 \% C I$ 1.06-1.84, $P=0.02), \quad\left(I^{2}=0 \%\right.$, 
$\mathrm{P}=0.89$ ). Moreover, a subgroup analysis indicated that NSCLC also showed significant differences between groups $(13.9 \%$ VS. $10.1 \%, \mathrm{RR}=1.50,95 \% \mathrm{CI} 1.05-2.13$, $\mathrm{P}=0.02$ ). The forest plot did not reveal a benefit of immunochemotherapy versus chemotherapy alone in terms of the 1-year irPFS (11.7\% VS. 9.0\%, RR $=1.33$, $95 \% \mathrm{CI} 0.57-3.10, \mathrm{P}=0.50$ ), and the results did not indicate much heterogeneity $\left(\mathrm{I}^{2}=22 \%, \mathrm{P}=0.28\right)$ (Figure 2$)$.

The ORR/irORR rates for immunochemotherapy and chemotherapy alone were 50.0\%/39.5\% and $52.3 \% / 32.4 \%$, respectively. No significant differences were found in the ORR ( $R R=1.00,95 \% \mathrm{CI}$ $0.87-1.13, \mathrm{P}=0.95)$ or in the irORR $(\mathrm{RR}=1.24,95 \% \mathrm{CI}$ 0.93-1.67, $\mathrm{P}=0.15$ ) between groups. The results for the ORR also did not show much heterogeneity among the studies $\left(\mathrm{I}^{2}=25 \%, \mathrm{P}=0.25\right)$, while the results for the irORR revealed little heterogeneity $\left(\mathrm{I}^{2}=0 \%, \mathrm{P}=0.55\right)$. The rate of DCR/irDCR for immunochemotherapy and chemotherapy alone were $82.0 \% / 81.6 \%$ and $87.7 \% / 87.4 \%$, respectively. Significant differences were observed in the DCR between groups $(R R=0.92$, 95\% CI 0.85-1.00, $\mathrm{P}=0.04$ ), but the results of the DCR showed a large amount of heterogeneity among the studies $\left(\mathrm{I}^{2}=62 \%, \mathrm{P}=0.02\right)$. However, no significant differences were observed in the $\mathrm{irDCR}$ between the two groups ( $R R=0.94,95 \% C I 0.85-1.03, P=0.20)$, with a small amount of heterogeneity $\left(\mathrm{I}^{2}=24 \%, \mathrm{P}=0.26\right)$ (Figure 3). In addition, the results of the analysis of the CR/irCR, PR/irPR, PD/irPD and SD/irSD are shown in Supplementary Table S3.

The overall incidence of grade III/IV AEs was $52.7 \%$ for the immunochemotherapy group and $41.3 \%$ for the chemotherapy group. No significant differences were found between the groups $(R R=1.27$, 95\% CI 0.99-1.65, P=0.06). Grade III/IV trAEs were observed in $48.7 \%$ and $40.2 \%$ of patients who received immunochemotherapy and chemotherapy alone, respectively. The differences were statistically significant, and a higher heterogeneity was found among the studies ( $R R=1.25,95 \% \mathrm{CI} 1.03-1.51, \mathrm{P}=0.02)$, $\left(\mathrm{I}^{2}=51 \%, \mathrm{P}=0.07\right)$; moreover, a subgroup analysis indicated that, for NSCLC, significant differences were observed between the groups (49.4\% VS. 35.9\%, $\mathrm{RR}=1.37,95 \% \mathrm{CI} 1.13-1.66, \mathrm{P}=0.002)$. The incidence of grade III/IV irAEs was $18.0 \%$ and $7.3 \%$ of patients who received immunochemotherapy and chemotherapy alone, respectively ( $R R=2.47,95 \% \mathrm{CI} 1.19-5.09$, $\mathrm{P}=0.01$ ), and no heterogeneity was found among the studies $\left(\mathrm{I}^{2}=0 \%, \mathrm{P}=0.96\right)$. The rate of grade III/IV AE-related discontinuations was $16.5 \%$ and $3.0 \%$ for the immunochemotherapy group and the chemotherapy group, respectively. The differences were also statistically significant $(\mathrm{RR}=2.76,95 \% \mathrm{CI}$ 1.15-6.61, $\mathrm{P}=0.02)$, and a large amount of heterogeneity was found in the studies $\left(\mathrm{I}^{2}=70 \%, \mathrm{P}=0.005\right)$. The subgroup analysis indicated that, for NSCLC, significant differences were observed between groups $(16.9 \%$ VS. $3.3 \%, \quad \mathrm{RR}=3.63, \quad 95 \% \mathrm{CI} 1.30-10.13, \mathrm{P}=0.01)$. The incidence of grade III/IV serious AEs was $24.7 \%$ for the immunochemotherapy group and $10.0 \%$ for the chemotherapy group, respectively. The differences were statistically significant ( $R R=2.50,95 \% C I$ 1.60-3.90, $\mathrm{P}<0.0001$ ) (Figure 4). In addition, the result of the analysis of the hematologic system, dermatological system, gastrointestinal system, neuromuscular system and toxic adverse events that occurred in other areas are shown in Table 2.

\section{Publication bias}

We used the funnel plots to determine the publication bias of the 6-month/1-year OS, the 6-month/1-year PFS, the ORR, DCR, trAEs and AE-related discontinuation (Supplementary Figure S2). The shape of the individual funnel plots showed a slight asymmetry, and the power of the test was insufficient because of a small number of studies. We also used STATA 14 software for Begg's and Egger's test for the 8 effect sizes mentioned above. The results demonstrated that only the 6-month-PFS and AE-related discontinuation may have shown potential bias $(\mathrm{P}<0.1)$. No obvious bias was indicated for the other endpoints[28, 29].

\section{Discussion}

Platinum-based chemotherapy has always been the standard treatment for the majority of advanced patients with lung cancer including NSCLC and ED-SCLC, but its clinical efficacy is limited, as a result, new treatments are emerging, including the addition of monoclonal immunotherapy[8, 11, 36]. Ipilimumab is a monoclonal antibody that binds the CD28 homolog CTLA-4, and upon binding, enhances the costimulation of $\mathrm{T}$ cells at their receptor by allowing the binding of CD28 to members of the B7 family on antigen-presenting cells[16]. In recent years, many studies have mentioned that immunotherapy and ipilimumab can enhance the therapeutic effect in cases of NSCLC and SCLC[37-39].

This meta-analysis suggests that chemotherapy combined with ipilimumab immunotherapy may improve the 6-month PFS/irPFS and the 1-year PFS compared with chemotherapy alone in patients with advanced or recurrent NSCLC and ED-SCLC. This improvement should be closely connected with the effect of ipilimumab's, and many studies have reported similar results[40, 41]. Arriola E et al. suggested that the median PFS was 6.9 months $(95 \%$ CI: 5.57 .9 ), that the median irPFS was 7.3 months (95\% CI: 5.58 .8 ) and that the median OS was 17.0 months (95\% CI: 7.9 24.3) in patients with ED-SCLC 
after they were treated with ipilimumab immunotherapy. They also showed that chemotherapy plus ipilimumab immunotherapy was beneficial for some patients with advanced SCLC[42]. However, in this meta-analysis, it was not suggested that chemotherapy combined with ipilimumab immunotherapy could improve the 6-month/1-year OS of patients with advanced or recurrent NSCLC and ED-SCLC. Previous studies have shown that the survival of NSCLC patients can improve when tumor infiltration by immune cells (CD4+/CD8+Tcells) is enhanced [43-46]. The results of this meta-analysis are somewhat inconsistent with this statement. One reason for this discrepancy is that the included patients all had advanced lung cancer, that those patients were prone to distant metastasis and recurrence, or that they had a poor prognosis[4]. Another reason is that ipilimumab enhanced the infiltration of the tumor cells via blocking CTLA-4 and a series of signal transduction pathways, but this did not completely eliminate the tumor cells.

This study further demonstrated that the ORR/irORR, and DCR/irDCR did not improve significantly as a result of the chemotherapy combined with ipilimumab immunotherapy. In addition, the integrated patients with lung cancer in the chemotherapy combined with ipilimumab immunotherapy group had a slightly inferior DCR than the chemotherapy group $(82.0 \%$ vs. $87.7 \%$ $\mathrm{RR}=0.92,95 \% \mathrm{CI} 0.85-1.00, \mathrm{P}=0.04)$. In 2016, a phase I/II CheckMate 032 study (nivolumab VS. nivolumab+ipilimumab) that included 216 patients with SCLC found that the RSS was $19 \%$ and $23 \%$, respectively, and that the DCRs were $36 \%$ and $42 \%$, respectively. They also found that, for the nivolumab and the nivolumab plus ipilimumab groups, the ORRs were $13 \%$ and $31 \%$, respectively, and that the median OS was 3.6 months and 7.8 months, respectively[47]. However, our ED-SCLC cases did not show a statistical advantage in terms of the efficacy of chemotherapy combined with ipilimumab immunotherapy in the subgroup analysis. A benefit is not ruled out because of the differences between nivolumab and chemotherapeutic drugs because the patients themselves might have had an advanced stage of the disease, and because these rates are associated with the natural progression of the disease and the extent of tumor shrinkage.
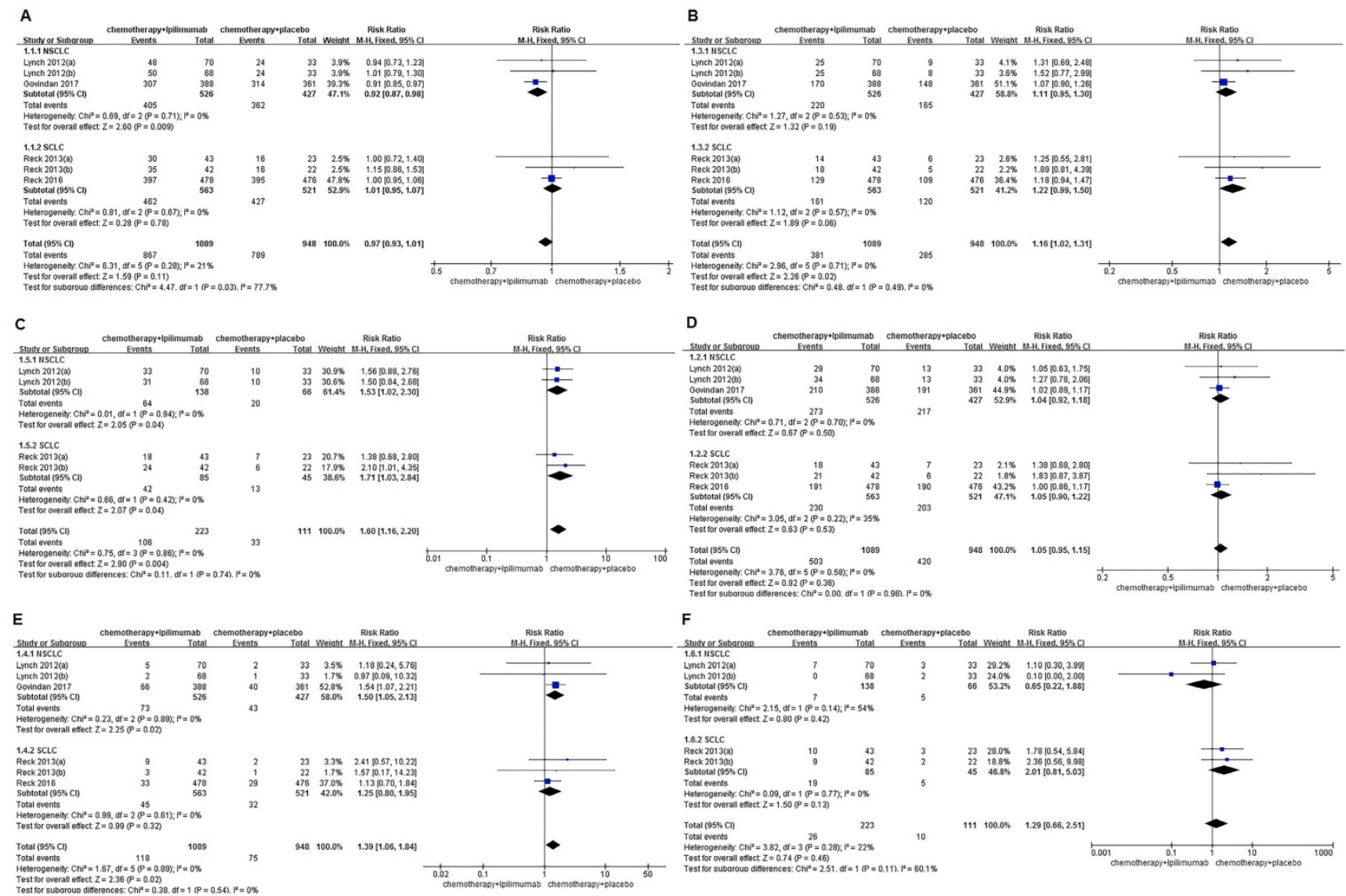

Figure 2. Forest plots for ipilimumab plus chemotherapy vs. chemotherapy alone trials of 6 months/lyear-overall survival(OS) (A/D), 6months/ lyear-progression-free survival(PFS) (B/E), 6months/ lyear-immune-related progression-free survival(irPFS) (C/F). 
Table 2. Results of the meta-analyses examining the adverse events between pure chemotherapy group and chemotherapy plus ipilimumab group

\begin{tabular}{|c|c|c|c|c|c|}
\hline \multirow[t]{2}{*}{ Toxicity } & \multirow[t]{2}{*}{$\mathbf{N}$} & Ipilimumab & Placebo & \multirow[t]{2}{*}{$\operatorname{RR}[95 \% \mathrm{CI}]$} & \multirow{2}{*}{$\begin{array}{l}\text { Heterogeneity } \\
\left(\mathbf{I}^{2}, \mathbf{P}\right)\end{array}$} \\
\hline & & \multicolumn{2}{|l|}{ No. $\geq$ Grade III } & & \\
\hline \multicolumn{6}{|l|}{ Hematologic } \\
\hline Anemia & 6 & $103 / 1088$ & 86 / 946 & $1.06[0.81-1.40]$ & $34 \%, 0.18$ \\
\hline$\bullet$ SCLC & 3 & 45 / 562 & $55 / 520$ & $0.77[0.53-1.12]$ & $0 \%, 0.60$ \\
\hline$\bullet$ NSCLC & 3 & $58 / 526$ & $31 / 426$ & $1.56[1.02-2.37]$ & $0 \%, 0.82$ \\
\hline Leukopenia & 2 & $17 / 866$ & $27 / 837$ & $0.61[0.33-1.11]$ & $42 \%, 0.19$ \\
\hline Neutropenia & 6 & $138 / 1088$ & $171 / 946$ & $0.75[0.61-0.92]$ & $45 \%, 0.10$ \\
\hline •SCLC & 3 & $76 / 562$ & $114 / 520$ & $0.64[0.49-0.84]$ & $25 \%, 0.26$ \\
\hline$\bullet$ NSCLC & 3 & 62 / 526 & $57 / 426$ & $0.94[0.67-1.31]$ & $31 \%, 0.23$ \\
\hline Thrombocytopenia & 6 & $53 / 1088$ & 42 / 946 & $0.89[0.41-1.90]$ & $51 \%, 0.07$ \\
\hline$\bullet$ SCLC & 3 & 22 / 562 & $22 / 520$ & $0.91[0.51-1.63]$ & $0 \%, 0.82$ \\
\hline$\bullet$ NSCLC & 3 & $31 / 526$ & $20 / 426$ & $0.52[0.08-3.21]$ & $78 \%, 0.01$ \\
\hline \multicolumn{6}{|l|}{ Gastrointestinal } \\
\hline Diarrhea & 6 & 77 / 1088 & 13 / 946 & 3.95 [1.97-7.95] & $18 \%, 0.30$ \\
\hline$\bullet$ SCLC & 3 & 41 / 562 & 5 / 520 & $3.80[0.78-18.51]$ & $55 \%, 0.11$ \\
\hline •NSCLC & 3 & 36 / 526 & $8 / 426$ & 3.52 [1.65-7.51] & $0 \%, 0.61$ \\
\hline Nausea & 6 & $10 / 1088$ & $5 / 946$ & 1.40 [0.51-3.83] & $0 \%, 0.56$ \\
\hline •SCLC & 3 & $7 / 562$ & 4 / 520 & 0.97 [0.09-10.58] & $54 \%, 0.14$ \\
\hline$\bullet$ NSCLC & 3 & $3 / 526$ & $1 / 426$ & $1.11[0.20-6.35]$ & $0 \%, 0.69$ \\
\hline Vomiting & 4 & 9 / 1004 & $7 / 902$ & $1.05[0.40-2.70]$ & $0 \%, 0.77$ \\
\hline$\bullet$ SCLC & 1 & 5 / 478 & $3 / 476$ & $1.66[0.40-6.91]$ & NA \\
\hline$\bullet$ NSCLC & 3 & $4 / 526$ & $4 / 426$ & $0.69[0.18-2.60]$ & $0 \%, 0.86$ \\
\hline \multicolumn{6}{|l|}{ Dermatological } \\
\hline Rash & 6 & $22 / 1088$ & $1 / 946$ & 5.75 [1.88-17.57] & $0 \%, 0.42$ \\
\hline$\bullet$ SCLC & 3 & $10 / 562$ & $0 / 520$ & 8.87[1.27-62.18] & $0 \%, 0.37$ \\
\hline -NSCLC & 3 & $12 / 526$ & $1 / 426$ & $4.34[1.09-17.26]$ & $22 \%, 0.28$ \\
\hline Pruritus & 6 & $8 / 1088$ & $1 / 946$ & 2.12 [0.36-12.59] & $27 \%, 0.25$ \\
\hline$\bullet$ SCLC & 3 & 4 / 562 & $0 / 520$ & $3.51[0.40-30.44]$ & $0 \%, 0.50$ \\
\hline •NSCLC & 3 & $4 / 526$ & $1 / 426$ & $1.21[0.02-61.85]$ & $70 \%, 0.07$ \\
\hline \multicolumn{6}{|l|}{ Neuromuscular } \\
\hline Peripheral neuropathy & 5 & $4 / 610$ & $2 / 470$ & $1.47[0.30-7.30]$ & $0 \%, 0.32$ \\
\hline$\bullet$ SCLC & 2 & $0 / 84$ & $0 / 44$ & NA & NA \\
\hline$\bullet$ NSCLC & 3 & $4 / 526$ & $2 / 426$ & $1.47[0.30-7.30]$ & $0 \%, 0.32$ \\
\hline Peripheralsensoryneuropathy & 5 & $8 / 610$ & $6 / 470$ & $0.98[0.37-2.60]$ & $0 \%, 0.43$ \\
\hline$\bullet$ SCLC & 2 & $0 / 84$ & $0 / 44$ & NA & NA \\
\hline • NSCLC & 3 & $8 / 526$ & $6 / 426$ & $0.98[0.37-2.60]$ & $0 \%, 0.43$ \\
\hline \multicolumn{6}{|l|}{ Others } \\
\hline Fatigue & 6 & $40 / 1088$ & $16 / 946$ & $1.87[1.06-3.31]$ & $0 \%, 0.46$ \\
\hline$\bullet$ SCLC & 3 & 19 / 562 & 3 / 520 & $4.54[1.44-14.31]$ & $0 \%, 0.39$ \\
\hline$\bullet$ NSCLC & 3 & $21 / 526$ & $13 / 426$ & $1.20[0.60-2.39]$ & $0 \%, 0.96$ \\
\hline Liver-function enzymes & 5 & 35 / 610 & $5 / 470$ & $3.71[1.60-8.60]$ & $27 \%, 0.24$ \\
\hline$\bullet$ SCLC & 2 & $18 / 84$ & $0 / 44$ & $10.16[1.40-73.51]$ & $0 \%, 0.65$ \\
\hline -NSCLC & 3 & $17 / 526$ & $5 / 426$ & $2.35[0.92-5.99]$ & $35 \%, 0.21$ \\
\hline
\end{tabular}

$\mathrm{N}$ = number of included studies; RR = relative risk. SCLC: Small Cell Lung Cancer; NSCLC: Non-Small Cell Lung Cancer. NA: not applicable.

We also performed a detailed subgroup analysis of the SCLC and NSCLC patients, which was similar to the comprehensive statistical results of all lung cancer patients, but there were still some important findings. For patients with advanced or recurrent NSCLC, the 1-year PFS of patients in the chemotherapy combined with ipilimumab treatment group was improved $(13.9 \%$ VS. $10.1 \% \mathrm{RR}=1.50,95 \% \mathrm{CI}$ 1.05-2.13, $\mathrm{P}=0.02$ ), but for patients with ED-SCLC, no statistically significant difference was found between the two groups, whether the chemotherapy of each group is paclitaxel combined with carboplatin (TC) or etoposide combined with carboplatin/cisplatin (EC) (Supplementary Figure S3). This may have depended on the exact tumor type of SCLC and NSCLC. Surprisingly, 6months-OS of patients with NSCLC was lower in chemotherapy plus ipilimumab group than in chemotherapy alone group $(77.0 \%$ VS. $84.8 \%$ $\mathrm{RR}=0.92,95 \% \mathrm{CI}$ 0.87-0.98, $\mathrm{P}=0.009$ ), while for patients with ED-SCLC, whether the chemotherapy is TC or EC, no statistically significant difference was observed between the two groups (Supplementary Figure S3). Although TC was rarely used for the treatment of ED-SCLC, the difference between this chemotherapy and the standard chemotherapy method EC did not affect the primary results of this meta-analysis. And of course, this finding suggests that ipilimumab does not improve the overall survival. This may be related to the points discussed above in that the patients included in the study have advanced disease and are prone to distant metastasis and recurrence. Moreover, ipilimumab may stimulate $\mathrm{T}$ cells that have infiltrated 
the tumor and may not completely eradicate the tumor cells. This meta-analysis also has a limited sample size. And we should take an objective view of its analysis results.

A

\begin{tabular}{|c|c|c|c|c|c|c|c|c|c|}
\hline \multirow[b]{2}{*}{ Study or Subqroup } & \multicolumn{2}{|c|}{ chemotherapy+|pilimumab } & \multicolumn{2}{|c|}{ chemotherapy+placebo } & & \multirow{2}{*}{$\begin{array}{l}\text { Risk Ratio } \\
-\mathrm{H}, \text { Random, } 95 \% \mathrm{Cl}\end{array}$} & \multirow{2}{*}{\multicolumn{3}{|c|}{$\begin{array}{l}\text { Risk Ratio } \\
\text { M-H, Random, } 95 \% \mathrm{Cl}\end{array}$}} \\
\hline & Events & Total & Events & Total & Weight & & & & \\
\hline \multicolumn{10}{|l|}{ 1.9.1 NSCLC } \\
\hline Lynch 2012(a) & 40 & 70 & 24 & 33 & $6.3 \%$ & $0.79[0.59,1.05]$ & & & \\
\hline Lynch 2012(b) & 53 & 68 & 24 & 33 & $8.3 \%$ & $1.07[0.84,1.37]$ & $t^{\circ}$ & & \\
\hline Govindan 2017 & 314 & 388 & 319 & 361 & $30.2 \%$ & $0.92[0.86,0.97]$ & & & \\
\hline Subtotal $(95 \% \mathrm{Cl})$ & & 526 & & 427 & $44.8 \%$ & $0.92[0.83,1.03]$ & & & \\
\hline Total events & 407 & & 367 & & & & & & \\
\hline \multirow{2}{*}{\multicolumn{10}{|c|}{$\begin{array}{l}\text { Heterogeneity: } \mathrm{Tau}^{2}=0.00 ; \mathrm{Ch}^{2}=2.65 \text {, df }=2(P=0.27) ; I^{2}=24 \% \\
\text { Test for overall effect: } Z=1.48(P=0.14)\end{array}$}} \\
\hline & & & & & & & & & \\
\hline \multicolumn{10}{|l|}{ 1.9.2 SCLC } \\
\hline Reck 2013(a) & 30 & 43 & 21 & 23 & $8.9 \%$ & $0.76[0.60,0.97]$ & & & \\
\hline Reck 2013(b) & 34 & 42 & 21 & 22 & $13.6 \%$ & $0.85[0.71,1.01]$ & $\rightarrow$ & & \\
\hline Reck 2016 & 422 & 478 & 422 & 476 & $32.7 \%$ & $1.00[0.95,1.04]$ & & & \\
\hline Subtotal $(95 \% \mathrm{Cl})$ & & 563 & & 521 & $55.2 \%$ & $0.89[0.75,1.05]$ & & & \\
\hline Total events & 486 & & 464 & & & & & & \\
\hline \multirow{2}{*}{\multicolumn{10}{|c|}{$\begin{array}{l}\text { Heterogeneity: } \mathrm{Tau}^{2}=0.01 ; \mathrm{Ch}^{2}=7.51, \mathrm{df}=2(P=0.02) ; \mathrm{I}^{2}=73 \% \\
\text { Test for overall effect: } Z=1.40(P=0.16)\end{array}$}} \\
\hline & & & & & & & & & \\
\hline Total $(95 \% \mathrm{Cl})$ & & 1089 & & 948 & $100.0 \%$ & $0.92[0.85,1.00]$ & $\bullet$ & & \\
\hline Total events & 893 & & 831 & & & & & & \\
\hline \multirow{2}{*}{\multicolumn{7}{|c|}{$\begin{array}{l}\text { Heterogeneity: } \operatorname{Tau}^{2}=0.00 ; \mathrm{Ch}^{2}=13.06, \mathrm{df}=5(P=0.02) ;\left.\right|^{2}=62 \% \\
\text { Test for overall effect: } Z=2.04(P=0.04)\end{array}$}} & & & 5 \\
\hline & & & & & & & $\begin{array}{l}0.2 \\
\text { chemotherapy+1pilimumab }\end{array}$ & chemotherapy+placebo & 3 \\
\hline
\end{tabular}

\section{B}

\begin{tabular}{|c|c|c|c|}
\hline & \multicolumn{3}{|c|}{ chemotherapy+|pilimumab } \\
\hline Study or Subqroup & Events & Total & Events \\
\hline \multicolumn{4}{|l|}{ 1.7.1 NSCLC } \\
\hline Lynch 2012(a) & 15 & 70 & 5 \\
\hline Lynch 2012(b) & 22 & 68 & 4 \\
\hline Govindan 2017 & 172 & 388 & 169 \\
\hline Subtotal $(95 \% \mathrm{Cl})$ & & 526 & \\
\hline Total events & 209 & & 178 \\
\hline \multicolumn{4}{|c|}{$\begin{array}{l}\text { Heterogeneity: } \operatorname{Tau}^{2}=0.18 ; \mathrm{Ch}^{2}=4.97, \mathrm{df}=2(P=0.08) ; I^{2}=60 \% \\
\text { Test for overall effect: } Z=0.89(P=0.37)\end{array}$} \\
\hline \multicolumn{4}{|l|}{ 1.7.2 SCLC } \\
\hline Reck 2013 (a) & 14 & 43 & 11 \\
\hline Reck 2013(b) & 24 & 42 & 11 \\
\hline Reck 2016 & 297 & 478 & 296 \\
\hline Subtotal $(95 \% \mathrm{Cl})$ & & 563 & \\
\hline Total events & 335 & & 318 \\
\hline \multicolumn{4}{|c|}{$\begin{array}{l}\text { Heterogeneity: } \operatorname{Tau}^{2}=0.00 ; \mathrm{Ch}^{2}=1.82, \mathrm{df}=2(P=0.40) ; I^{2}=0 \% \\
\text { Test for overall effect: } Z=0.11(P=0.91)\end{array}$} \\
\hline Total $(95 \% \mathrm{Cl})$ & & 1089 & \\
\hline & 544 & & 496 \\
\hline Heterogeneity: $\mathrm{Tau}^{2}=$ & $0.01 ; \mathrm{Ch}^{2}=6.68$ & $(P=0.2$ & $25) ; 1^{2}=25 \%$ \\
\hline Test for overall effect & $Z=0.07(P=0.9$ & & \\
\hline
\end{tabular}

rebo Total Weight M-H. Random. $95 \% \mathrm{Cl}$

\section{$33 \quad 1.9 \% \quad 1.41[0.56,3.56]$} $\begin{array}{lll}33 & 1.7 \% & 2.67[1.00,7.12]\end{array}$ $\begin{array}{lll}361 & 35.1 \% & 0.95[0.81,1.11] \\ 427 & 38.7 \% & \mathbf{1 . 3 2}[0.72,2.45]\end{array}$

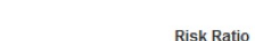

C

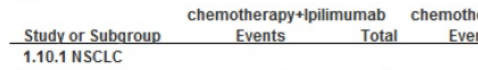
Lynch 2012 (a) Lynch 2012(b) Subtotal $(95 \% \mathrm{Cl})$ Totat events
Heterogeneity: Tau $^{2}=0.01 ; \mathrm{Chi}^{2}=2.15, \mathrm{df}=1(\mathrm{P}=0.14) ; \mathrm{I}^{2}=53 \%$

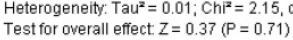

1.10.2 SCLC

Reck 2013 (a)

Reck $2013($ b)

Total events

Heterogeneity: $\operatorname{Tau}^{2}=0.00 ; \mathrm{Ch}^{2}=1.72, \mathrm{df}=1(\mathrm{P}=0.19) ; \mathrm{I}^{2}=42 \%$

Test for overall effect $Z=1.21(\mathrm{P}=0.23)$

Total $(95 \% \mathrm{Cl})$

Total events $\quad 182 \quad 97$

Heterogeneity. $\mathrm{Tau}^{2}=0.00 ; \mathrm{Ch}^{2}=3.97$, d

Test for subaroun differences: $\mathrm{Ch}^{2}=0.11 . \mathrm{df}=1(\mathrm{P}=0.73) \mathrm{f}^{2}=0 \%$

$\begin{array}{rrr}23 & 4.3 \% & 0.68[0.37,1.25] \\ 22 & 6.3 \% & 1.14[0.70,1.87] \\ 476 & 50.7 \% & 1.00[0.90,1.10] \\ 521 & 61.3 \% & 0.99[0.90,1.09]\end{array}$

$\begin{array}{lll}476 & 50.7 \% & 1.00[0.90,1.10] \\ 521 & 61.3 \% & 0.99[0.90,1.09]\end{array}$

$948 \quad 100.0 \% \quad 1.00[0.87,1.13]$ Risk Ratio
Random. $95 \%$

D

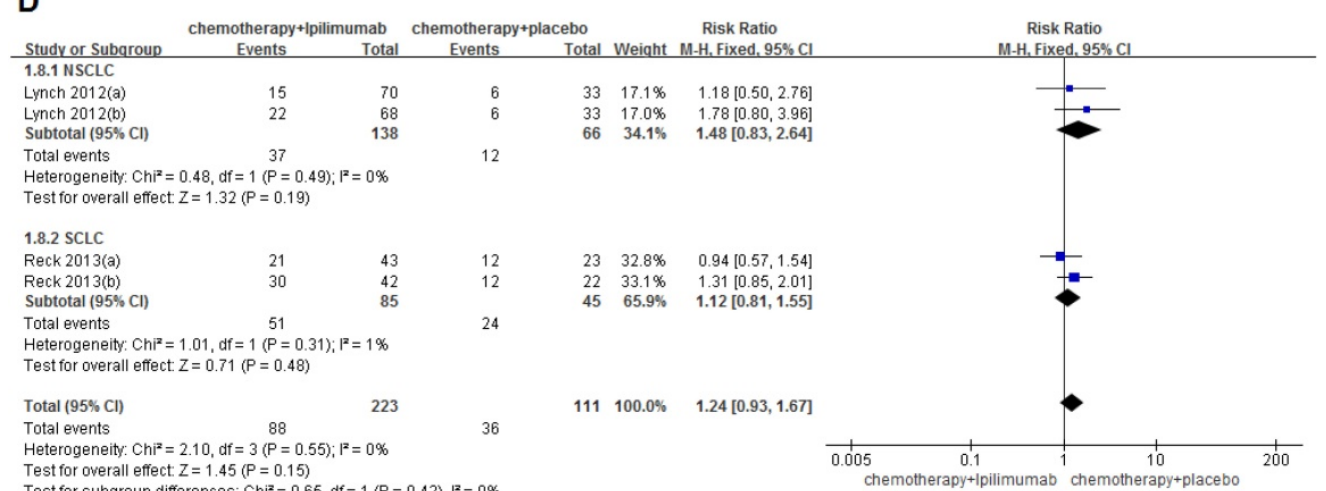

Figure 3. Forest plots for ipilimumab plus chemotherapy vs. chemotherapy alone trials of disease control rate(DCR) (A), objective response rate(ORR) (B), immune related disease control rate(irDCR) (C), immune related objective response rate(irORR) (D). 
A

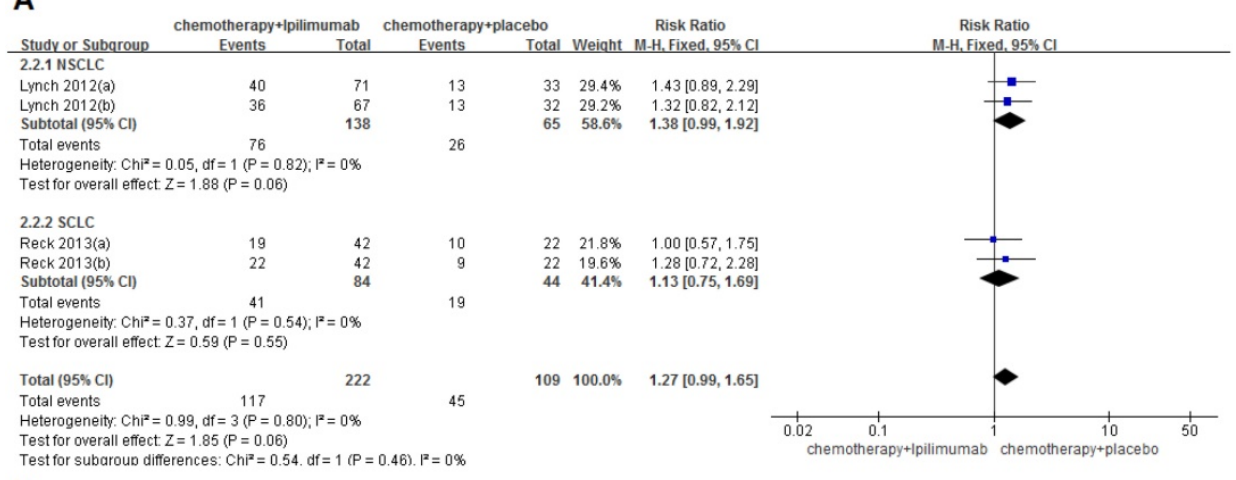

B

$\begin{array}{lll}\text { chemotherapy+lipilimumab } & \text { chemotherapy+placebo } \\ \text { Study or Subaroup } & \text { Events } & \text { Total } \\ \text { Events } & \text { Tota }\end{array}$

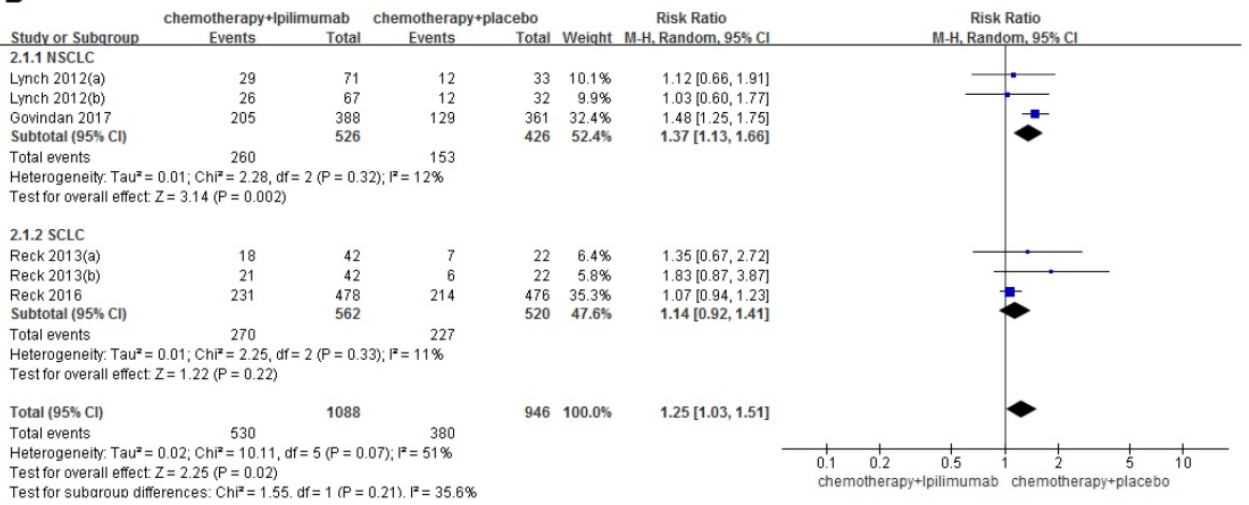

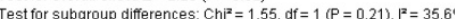

C

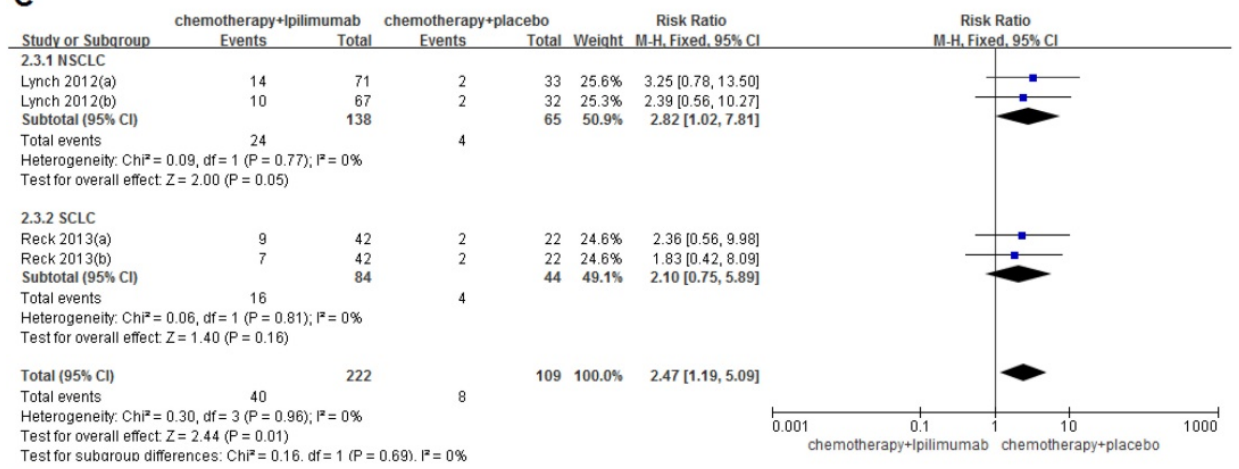

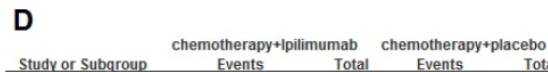

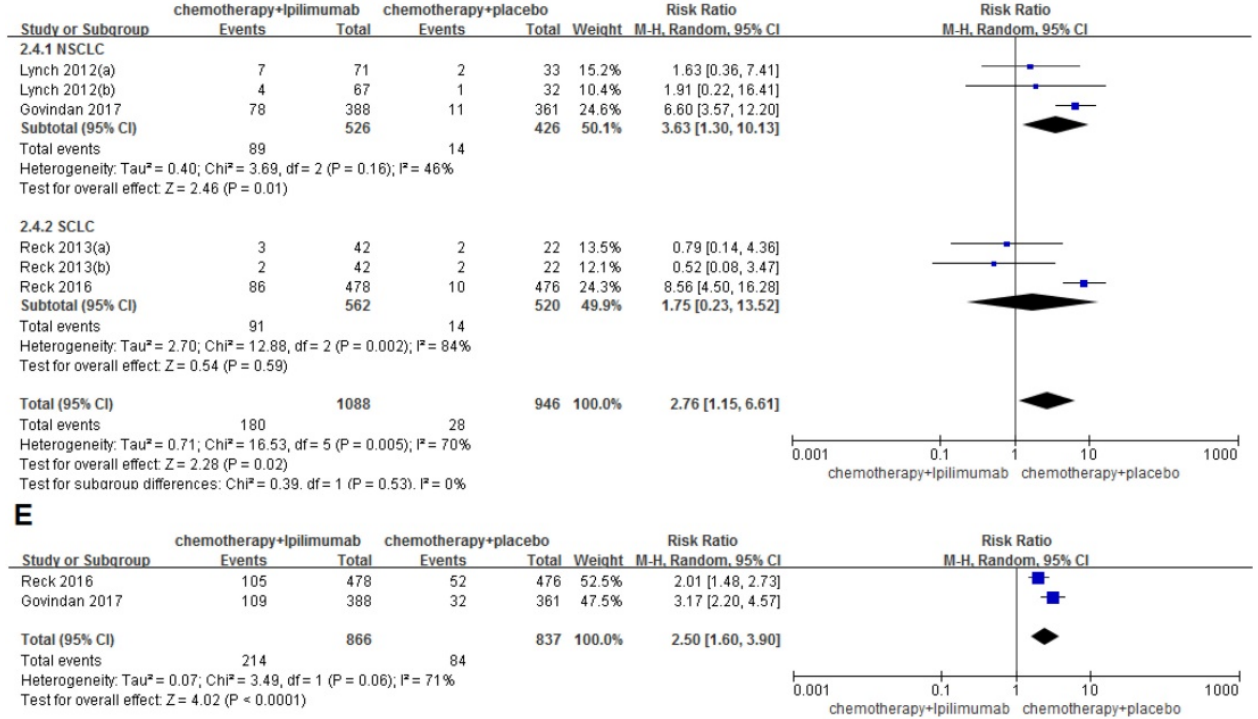

Figure 4. Forest plots for ipilimumab plus chemotherapy vs. chemotherapy alone trials of adverse events(AEs) (A), treatment-related adverse events(trAEs) (B), immune related adverse events(irAEs) (C), adverse event(AE)-related discontinuation (D), serious adverse events (AEs). The above mentioned toxicities are grade III/IV. 
In addition, subgroup analysis was also performed for the split phased-ipilimumab regimen and concurrent-ipilimumab regimen. For primary outcome, the results are similar to the overall results, but there were still some differences. The 6months-OS of patients with NSCLC in phased-ipilimumab regimen was lower in chemotherapy plus ipilimumab group than in chemotherapy alone group (78.3\% VS. $85.8 \% \mathrm{RR}=0.9295 \% \mathrm{CI} 0.86-0.98, \mathrm{P}=0.009)$, this is consistent with the above results, while in concurrentipilimumab regimen, no statistically significant difference was observed between the study group and control group. Perhaps such results suggest that phased-ipilimumab regimen makes ipilimumab less meaningful than concurrent-ipilimumab regimen. And of course, this suggests that ipilimumab does not improve the overall survival. We hypothesized that this effect might be altered by an increase in the sample size of the concurrent-ipilimumab group (Supplementary Figure S4).

Quality of life is particularly important for cancer patients. Chemotherapy is a first-line treatment for cancer, and thus its toxic adverse events are the focus of patients and medical professionals. For cisplatin, a drug that highly induces vomiting is the gold standard for adjuvant chemotherapy. Since carboplatin causes less vomiting than cisplatin, it is more internationally recommended for patients with more complications, although it is still not possible to avoid the toxic effects of chemotherapy drugs[48]. Ipilimumab can specifically block the binding of CTLA-4 and its ligand (CD80/CD86) to achieve an immunotherapeutic effect[18]. However, the immune function of the human body has different degrees of influence. Immune checkpoint blockers (ICBs) strengthen the immune response against tumor cells, but they also cause immune-related adverse events[49]. We compared the grade III/IV toxicities in the two groups and found that the chemotherapy combined with ipilimumab immunotherapy group had the highest incidence of tr-AEs, ir-AEs, serious AEs and AE-related discontinuation and determined that the difference was statistically significant. Ipilimumab did not aggravate fatigue, alopecia, vomiting, nausea and other chemotherapy-related adverse events, but immune-related skin mucosal toxicity was aggravated by the addition of ipilimumab.

In addition, there are two potential limitations of this meta-analysis:

- although we performed a detailed subgroup analysis for advanced or recurrent NSCLC and SCLC patients, a comprehensive analysis revealed that these patients will inevitably have more sources of heterogeneity because of different tumor types;
- for the studies by Lynch et al.[30] and Reck et al[31], we divided the control group into two separate groups so that they corresponded to the two experimental groups, which also increased the sources of heterogeneity[34].

\section{Conclusions}

In summary, chemotherapy combined with ipilimumab immunotherapy cannot improve the OS, ORR, DCR of patients with lung cancer (NSCLC, ED-SCLC) compared with chemotherapy alone, but it can improve the patient's 6-month/1-year PFS and 6-month-irPFS; a subgroup analysis suggests that 1-year PFS is more improved in patients with advanced or recurrent NSCLC in the chemotherapy plus ipilimumab immunotherapy group. However, due to the addition of ipilimumab, the tr-AEs, ir-AEs, serious $\mathrm{AEs}$ and AE-related discontinuation are relatively higher in this group than in the chemotherapy only group, in which the immune-related toxicities are more apparent, and the quality of the patient's life has been affected. We hope this meta-analysis can play a role in evidence-based medicine and clinical work, but we must have a dialectical view of the results. Nevertheless, for further research and exploration, we need additional larger, multi-center studies that include more detailed types of tumors and that strictly control the type and dosage of chemotherapeutics.

\section{Supplementary Material}

Supplementary figures and tables. http://www.jcancer.org/v09p4556s1.pdf

\section{Acknowledgements}

Jian Zhang and Peng Luo designed the study; Hongman Zhang and Jie Shen collected the data; Hongman Zhang and Jie Shen performed the statistical analysis and wrote the first draft of the manuscript; all authors (Hongman Zhang, Jie Shen, Lilan Yi, Wei Zhang, Peng Luo, Jian Zhang) contributed to the interpretation of the results and critically reviewed the first draft of the manuscript. All authors gave final approval for submission of the manuscript.

\section{Funding}

The work supported by the National Natural Science Foundation of China (81672267) and the Natural Science Foundation of Guangdong Province, China (2016A030313632).

\section{Competing Interests}

The authors have declared that no competing interest exists. 


\section{References}

1. Siegel R, Ma J, Zou Z, Jemal A. Cancer statistics, 2014. CA: a cancer journal for clinicians. 2014; 64: 9-29.

2. Ferlay J, Soerjomataram I, Dikshit R, Eser S, Mathers C, Rebelo M, et al. Cancer incidence and mortality worldwide: sources, methods and major patterns in GLOBOCAN 2012. International journal of cancer. 2015; 136: E359-86.

3. Basumallik N, Agarwal M. Cancer, Lung, Small Cell (Oat Cell). StatPearls. Treasure Island (FL): StatPearls Publishing StatPearls Publishing LLC. 2018.

4. Camps C, del Pozo N, Blasco A, Blasco P, Sirera R. Importance of quality of life in patients with non-small-cell lung cancer. Clinical lung cancer. 2009; 10: 83-90.

5. Wei T, Zhu W, Fang S, Zeng X, Huang J, Yang J, et al. miR-495 promotes the chemoresistance of SCLC through the epithelial-mesenchymal transition via Etk/BMX. American journal of cancer research. 2017; 7: 628-46.

6. Baka S, Agelaki S, Kotsakis A, Veslemes M, Papakotoulas P, Agelidou M, et al. Phase III study comparing sequential versus alternate administration of cisplatin-etoposide and topotecan as first-line treatment in small cell lung cancer. Anticancer research. 2010; 30: 3031-8.

7. Schuette WH, Groschel A, Sebastian M, Andreas S, Muller T, Schneller F, et al. A randomized phase II study of pemetrexed in combination with cisplatin or carboplatin as first-line therapy for patients with locally advanced or metastatic non-small-cell lung cancer. Clinical lung cancer. 2013; 14: 215-23.

8. Mencoboni M, Filiberti RA, Taveggia P, Del Corso L, Del Conte A, Covesnon MG, et al. Safety of First-line Chemotherapy with Metronomic Single-agent Oral Vinorelbine in Elderly Patients with NSCLC. Anticancer research. 2017; 37: 3189-94.

9. Eckardt JR, von Pawel J, Papai Z, Tomova A, Tzekova V, Crofts TE, et al. Open-label, multicenter, randomized, phase III study comparing oral topotecan/cisplatin versus etoposide/cisplatin as treatment for chemotherapy-naive patients with extensive-disease small-cell lung cancer. Journal of clinical oncology: official journal of the American Society of Clinical Oncology. 2006; 24: 2044-51.

10. Horn L, Dahlberg SE, Sandler AB, Dowlati A, Moore DF, Murren JR, et al. Phase II study of cisplatin plus etoposide and bevacizumab for previously untreated, extensive-stage small-cell lung cancer: Eastern Cooperative Oncology Group Study E3501. Journal of clinical oncology: official journal of the American Society of Clinical Oncology. 2009; 27: 6006-11.

11. Haslam S, Chrisp P. Bevacizumab: the evidence for its clinical potential in the treatment of nonsmall cell lung cancer. Core evidence. 2007; 2: 31-49.

12. Reck M, von Pawel J, Zatloukal P, Ramlau R, Gorbounova V, Hirsh V, et al. Phase III trial of cisplatin plus gemcitabine with either placebo or bevacizumab as first-line therapy for nonsquamous non-small-cell lung cancer: AVAil. Journal of clinical oncology: official journal of the American Society of Clinical Oncology. 2009; 27: 1227-34.

13. Socinski MA, Saleh MN, Trent DF, Dobbs TW, Zehngebot LM, Levine MA, et al. A randomized, phase II trial of two dose schedules of carboplatin/paclitaxel/cetuximab in stage IIIB/IV non-small-cell lung cancer (NSCLC). Annals of oncology : official journal of the European Society for Medical Oncology. 2009; 20: 1068-73.

14. Krummel MF, Allison JP. CD28 and CTLA-4 have opposing effects on the response of T cells to stimulation. The Journal of experimental medicine. 1995; 182: $459-65$

15. Walunas TL, Lenschow DJ, Bakker CY, Linsley PS, Freeman GJ, Green JM, et al. Pillars article: CTLA-4 can function as a negative regulator of $\mathrm{T}$ cell activation. Immunity. 1994. 1: 405-413. Journal of immunology (Baltimore, Md : 1950). 2011; 187: 3466-74.

16. Hoos A, Ibrahim R, Korman A, Abdallah K, Berman D, Shahabi V, et al. Development of ipilimumab: contribution to a new paradigm for cancer immunotherapy. Seminars in oncology. 2010; 37: 533-46.

17. Chambers CA, Allison JP. Costimulatory regulation of $\mathrm{T}$ cell function. Current opinion in cell biology. 1999; 11: 203-10.

18. Klein O, Ebert LM, Nicholaou T, Browning J, Russell SE, Zuber M, et al. Melan-A-specific cytotoxic $\mathrm{T}$ cells are associated with tumor regression and autoimmunity following treatment with anti-CTLA-4. Clinical cancer research: an official journal of the American Association for Cancer Research. 2009; 15: 2507-13.

19. Maker AV, Phan GQ, Attia P, Yang JC, Sherry RM, Topalian SL, et al. Tumor regression and autoimmunity in patients treated with cytotoxic $T$ lymphocyte-associated antigen 4 blockade and interleukin 2: a phase I/II study. Annals of surgical oncology. 2005; 12: 1005-16.

20. Small EJ, Tchekmedyian NS, Rini BI, Fong L, Lowy I, Allison JP. A pilot trial of CTLA-4 blockade with human anti-CTLA-4 in patients with hormone-refractory prostate cancer. Clinical cancer research: an official journal of the American Association for Cancer Research. 2007; 13: 1810-5.

21. Wolchok JD, Neyns B, Linette G, Negrier S, Lutzky J, Thomas L, et al. Ipilimumab monotherapy in patients with pretreated advanced melanoma: a randomised, double-blind, multicentre, phase 2, dose-ranging study. The Lancet Oncology. 2010; 11: 155-64.

22. Merritt RE, Mahtabifard A, Yamada RE, Crystal RG, Korst RJ. Cisplatin augments cytotoxic T-lymphocyte-mediated antitumor immunity in poorly immunogenic murine lung cancer. The Journal of thoracic and cardiovascular surgery. 2003; 126: 1609-17.
23. Jure-Kunkel M, Masters G, Girit E, Dito G, Lee F, Hunt JT, et al. Synergy between chemotherapeutic agents and CTLA-4 blockade in preclinical tumor models. Cancer immunology, immunotherapy : CII. 2013; 62: 1533-45.

24. Lee F, Jure-Kunkel MN, Salvati ME. Synergistic activity of ixabepilone plus other anticancer agents: preclinical and clinical evidence. Therapeutic advances in medical oncology. 2011; 3: 11-25.

25. Higgins JP, Altman DG, Gotzsche PC, Juni P, Moher D, Oxman AD, et al. The Cochrane Collaboration's tool for assessing risk of bias in randomised trials. BMJ (Clinical research ed). 2011; 343: d5928.

26. Bischoff P, Kubilay NZ, Allegranzi B, Egger M, Gastmeier P. Effect of laminar airflow ventilation on surgical site infections: a systematic review and meta-analysis. The Lancet Infectious diseases. 2017; 17: 553-61.

27. Huedo-Medina TB, Sanchez-Meca J, Marin-Martinez F, Botella J. Assessing heterogeneity in meta-analysis: Q statistic or I2 index? Psychological methods. 2006; 11: 193-206.

28. Begg CB, Mazumdar M. Operating characteristics of a rank correlation test for publication bias. Biometrics. 1994; 50: 1088-101.

29. Egger M, Davey Smith G, Schneider M, Minder C. Bias in meta-analysis detected by a simple, graphical test. BMJ (Clinical research ed). 1997; 315: 629-34.

30. Lynch TJ, Bondarenko I, Luft A, Serwatowski P, Barlesi F, Chacko R, et al. Ipilimumab in combination with paclitaxel and carboplatin as first-line treatment in stage IIIB/IV non-small-cell lung cancer: results from a randomized, double-blind, multicenter phase II study. Journal of clinical oncology: official journal of the American Society of Clinical Oncology. 2012; 30: 2046-54.

31. Reck M, Bondarenko I, Luft A, Serwatowski P, Barlesi F, Chacko R, et al. Ipilimumab in combination with paclitaxel and carboplatin as first-line therapy in extensive-disease-small-cell lung cancer: results from a randomized, double-blind, multicenter phase 2 trial. Annals of oncology: official journal of the European Society for Medical Oncology. 2013; 24: 75-83.

32. Reck M, Luft A, Szczesna A, Havel L, Kim SW, Akerley W, et al. Phase III Randomized Trial of Ipilimumab Plus Etoposide and Platinum Versus Placebo Plus Etoposide and Platinum in Extensive-Stage Small-Cell Lung Cancer. J Clin Oncol. 2016; 34: 3740-8.

33. Govindan R, Szczesna A, Ahn MJ, Schneider CP, Gonzalez Mella PF, Barlesi F, et al. Phase III Trial of Ipilimumab Combined With Paclitaxel and Carboplatin in Advanced Squamous Non-Small-Cell Lung Cancer. J Clin Oncol. 2017; 35: 3449-57.

34. Higgins JPT GSe. Cochrane Handbook for Systematic Reviews of Interventions Version 5.1.0[updated March 2011]. 2011. Available from www.cochrane-handbook.org.

35. Kay FU, Kandathil A, Batra K, Saboo SS, Abbara S, Rajiah P. Revisions to the Tumor, Node, Metastasis staging of lung cancer (8(th) edition): Rationale, radiologic findings and clinical implications. World journal of radiology. 2017; 9: 269-79.

36. Carter BW, Halpenny DF, Ginsberg MS, Papadimitrakopoulou VA, de Groot PM. Immunotherapy in Non-Small Cell Lung Cancer Treatment: Current Status and the Role of Imaging. Journal of thoracic imaging. 2017; 32: 300-12.

37. Hellmann MD, Rizvi NA, Goldman JW, Gettinger SN, Borghaei H, Brahmer $\mathrm{JR}$, et al. Nivolumab plus ipilimumab as first-line treatment for advanced non-small-cell lung cancer (CheckMate 012): results of an open-label, phase 1, multicohort study. The Lancet Oncology. 2017; 18: 31-41.

38. Ott PA, Elez E, Hiret S, Kim DW, Morosky A, Saraf S, et al. Pembrolizumab in Patients With Extensive-Stage Small-Cell Lung Cancer: Results From the Phase Ib KEYNOTE-028 Study. Journal of clinical oncology : official journal of the American Society of Clinical Oncology. 2017; 35: 3823-9.

39. Soo RA, Stone ECA, Cummings KM, Jett JR, Field JK, Groen HJM, et al. Scientific Advances in Thoracic Oncology 2016. Journal of thoracic oncology : official publication of the International Association for the Study of Lung Cancer. 2017; 12: 1183-209.

40. Genova C, Rijavec E, Barletta G, Sini C, Dal Bello MG, Truini M, et al. Ipilimumab (MDX-010) in the treatment of non-small cell lung cancer. Expert opinion on biological therapy. 2012; 12: 939-48.

41. Hardy-Werbin M, Arpi O, Taus A, Rocha P, Joseph-Pietras D, Nolan L, et al. Assessment of neuronal autoantibodies in patients with small cell lung cancer treated with chemotherapy with or without ipilimumab. Oncoimmunology. 2018; 7: e1395125.

42. Arriola E, Wheater M, Galea I, Cross N, Maishman T, Hamid D, et al Outcome and Biomarker Analysis from a Multicenter Phase 2 Study of Ipilimumab in Combination with Carboplatin and Etoposide as First-Line Therapy for Extensive-Stage SCLC. Journal of thoracic oncology : official publication of the International Association for the Study of Lung Cancer. 2016; 11: 1511-21.

43. Al-Shibli KI, Donnem T, Al-Saad S, Persson M, Bremnes RM, Busund LT. Prognostic effect of epithelial and stromal lymphocyte infiltration in non-small cell lung cancer. Clinical cancer research : an official journal of the American Association for Cancer Research. 2008; 14: 5220-7.

44. Ruffini E, Asioli S, Filosso PL, Lyberis P, Bruna MC, Macri L, et al. Clinical significance of tumor-infiltrating lymphocytes in lung neoplasms. The Annals of thoracic surgery. 2009; 87: 365-71; discussion 71-2.

45. Wakabayashi O, Yamazaki K, Oizumi S, Hommura F, Kinoshita I, Ogura S, et al. CD4+ T cells in cancer stroma, not CD8+ T cells in cancer cell nests, are associated with favorable prognosis in human non-small cell lung cancers. Cancer science. 2003; 94: 1003-9. 
46. Zhuang X, Xia X, Wang C, Gao F, Shan N, Zhang L, et al. A high number of CD8+ T cells infiltrated in NSCLC tissues is associated with a favorable prognosis. Applied immunohistochemistry \& molecular morphology : AIMM. 2010; 18: 24-8.

47. Antonia SJ, Lopez-Martin JA, Bendell J, Ott PA, Taylor M, Eder JP, et al. Nivolumab alone and nivolumab plus ipilimumab in recurrent small-cell lung cancer (CheckMate 032): a multicentre, open-label, phase 1/2 trial. The Lancet Oncology. 2016; 17: 883-95.

48. Dong X, Huang J, Cao R, Liu L. Palonosetron for prevention of acute and delayed nausea and vomiting in non-small-cell lung carcinoma patients. Medical oncology (Northwood, London, England). 2011; 28: 1425-9.

49. Helissey C, Vicier C, Champiat S. The development of immunotherapy in older adults: New treatments, new toxicities? Journal of geriatric oncology. 2016; 7: 325-33. 